\title{
Emotions for sale: cigarette advertising and women's psychosocial needs
}

\author{
S J Anderson, S A Glantz, P M Ling
}

Tobacco Control 2005;14:127-135. doi: 10.1136/tc.2004.009076

See end of article for authors' affiliations .....................

Correspondence to: Pamela M Ling, $M D, M P H$, , Box 0320, University of California San Francisco, CA 941430320, USA; pling@ medicine.ucsf.edu

Received 24 June 2004 Accepted

16 December 2004 hosocial needs satisfaction in cigarette advertising targeting Objective: To explore messages of psychosocial
women and implications for tobacco control policy. Methods: Analysis of internal tobacco industry documents and public advertising collections. Results: Tobacco industry market research attempted to identify the psychosocial needs of different groups of women, and cigarette advertising campaigns for brands that women smoke explicitly aimed to position cigarettes as capable of satisfying these needs. Such positioning can be accomplished with advertising that downplays or excludes smoking imagery. As women's needs change with age and over time, advertisements were developed to reflect the needs encountered at different stages in women's lives. Cigarette brands for younger women stressed female camaraderie, self confidence, freedom, and independence; cigarette brands for older women addressed needs for pleasure, relaxation, social acceptability, and escape from daily stresses.

Conclusions: Psychosocial needs satisfaction can be communicated without reference to cigarettes or smoking. This may explain why partial advertising bans are ineffective and comprehensive bans on all forms of tobacco marketing are effective. Counter-advertising should attempt to expose and undermine the needs satisfaction messages of cigarette advertising campaigns directed at women.
$\mathrm{T}$ obacco companies target women and other special populations with advertising. ${ }^{1-4}$ When cigarette marketing in the USA specifically targeted women in the 1920 s and 1930s, and again in the late 1960s, female smoking increased. ${ }^{5}$ Advertising aims to elicit emotional responses from its audiences. As early as 1911 psychology of marketing theorist Walter D Scott said, "[t]he man with the proper imagination is able to conceive of any commodity in such a way that it becomes an object of emotion to him and to those to whom he imparts his picture... the good advertiser... should be a practical psychologist and know the human emotions and sentiments...". ${ }^{6}$

Consumers "may feel they are purchasing a self-image". ${ }^{5}$ To sell these images, marketers need to determine consumers' interpersonal concerns and what images will promote the desired self enhancement. In an early study Koponen ${ }^{7}$ showed that purchasing behaviours were correlated with scores on standardised personality inventories. During the 1960s and 1970s, research on consumer lifestyles, ${ }^{8}$ psychological study of values, ${ }^{9}$ and market research on psychographics ${ }^{10}$ were used by business for a better understanding of the motivations of different consumer groups to develop more focused advertising. Using Virginia Slims as a case study, O'Keefe and Pollay ${ }^{11}$ found that Philip Morris identified a female market niche, the feminist values of individuals in that niche, and the stimuli to which they respond as they attempt to fill their needs.

Researchers have noted the psychological and emotional needs of female smokers and the advertisements that appeal to such needs. Associating smoking with slimness has been shown to encourage smoking initiation among adolescent girls and young women. ${ }^{12}{ }^{13}$ Fashionableness, sex appeal, affluence, independence, and adventure have been identified as themes found in female targeted cigarette advertising. ${ }^{5}{ }^{14-17}$ Advertising for cigarettes smoked by women only (such as Virginia Slims, Eve, Kim, and Satin) gave women a sense of equality, exclusivity, ${ }^{11}{ }^{18}$ and liberation. ${ }^{19}$
Although tobacco advertising targeting women has been documented, ${ }^{5}$ less is known about how needs satisfaction messages effectively promote smoking to women. Tobacco industry documents provide a unique opportunity to examine the industry's process of developing cigarette advertising for women. Between 1980 and 2000, cigarette advertisements designed to appeal to women increasingly paired smoking with the satisfaction of psychosocial needs that industry research identified as salient to women of different ages and life experiences.

\section{METHODS}

We searched the Legacy Tobacco Documents Library (http:// legacy.library.ucsf.edu), Tobacco Documents Online (http:// tobaccodocuments.org), and the documents websites of Philip Morris (http://www.pmdocs.com), Brown and Williamson (http://www.bwdocs.com), RJ Reynolds (http:// www.rjrtdocs.com), and Lorillard (http://www.lorillarddocs. com). Initial search terms included women, female, marketing, creative, focus group, qualitative, exploration, segmentation, psychology, promotion, advertising, brand names, and industry acronyms (for example, "YAFS" for young adult female smokers). These searches yielded tens of thousands of documents.

We conducted additional snowball searches on names of individuals and agencies, places, dates, Bates numbers, and campaign slogans. Documents related to research, planning, and evaluation of advertising to women were selected. This analysis is based upon a final collection of 704 documents.

We matched advertising images with the campaigns described in industry documents using print advertising and promotional items from the University of California, San Francisco Professor Virginia Ernster's tobacco advertising collection and various online sources, including the Pollay collection (http://roswell.tobaccodocuments.org/pollay/dirdet. (fm), the Tobacco Advertising Gallery of Tobacco-Free Kids (http://tobaccofreekids.org/adgallery), and other digital 
collections (http://www.geocities.com/SouthBeach/Palms/ 2120/capriads.htm, http://chickenhead.com/truth, http:// www.trinketsandtrash.org, http://www.gaysmokeout.net/ resource7.html). We collected 159 advertisements for this analysis.

We selected campaigns based upon a stated intent to target women in marketing plans, the apparent targeting of women using women dominated images in advertisements, or brand sales reports indicating a high percentage of female consumers. Although not every campaign discussed here exclusively or explicitly targets women, these criteria allowed us to analyse both female and unisex brands that claim a large proportion of women in the market. The brands and campaigns discussed were selected to present a sample of campaigns designed for different age groups, different psychographic segmentation schemes, and by different tobacco companies.

\section{RESULTS}

Tobacco marketers have noted that messages focusing on physical product characteristics are weak on personal relevance. ${ }^{20}$ Marketers rely on clusters of values and lifestyle preferences to develop brand images that would be psychologically, emotionally, and socially relevant to potential brand users. ${ }^{21}$ Table 1 summarises some of the needs of female target markets identified by industry research and the advertising designed to address those needs. We present several examples of campaigns for brands that target specific psychographic segments of the female market, emphasising campaigns that intended to suggest the satisfaction of psychosocial needs.

\section{"Spoil yourself": positioning satin for mature, feminine women}

Lorillard began test marketing Satin on 14 June $1982^{42}$ to compete in the growing market of educated working women who smoked slim cigarettes ${ }^{43}$; the campaign received very positive responses. ${ }^{44}$ Satin was positioned "to communicate to working women as well as housewives that they deserve some time for themselves; time to relax and spoil themselves in some manner and to further foster the moment is to smoke Satin cigarettes". ${ }^{45}$ The women targeted were mature, highly feminine women who experienced many daily demands on their time and energy ${ }^{46}$ and who shared a need for private, self indulgent, escapism. ${ }^{23}$ According to a 1981 Russell Marketing Research report to Lorillard, for test market respondents in cities across the USA, the Satin proposition most strongly appealed to "The sensuous nature of a woman... The desire to 'pamper yourself'... The desire to relax with a cigarette... The generally suppressed dream of relaxing in luxury". ${ }^{46}$ The research firm tested Satin for its ability to "relate to several major areas of a woman's motivation" and to "make her susceptible to appeals based on those drives which hold the most meaning for her whether conscious or subconscious ${ }^{\prime \prime 46}$ (emphasis in original). Lorillard hired MCA Advertising, Inc to develop advertisements that would involve women in a fantasy of "escape from life's problems with a little well-deserved, self-indulgence", and found that such a fantasy "seems to really be striking a nerve" ${ }^{\prime 22}$ with focus groups, especially with older women. ${ }^{47}$

In 1981 focus group testing of prototype advertisements, one image called the "'Couch' Ad had the best overall acceptance and involvement. It was self-indulgent, luxurious and sensuous, and went well with Satin... The group identified easily with it-'can fantasize with it"".23 This rendering depicted a solitary woman lounging on a couch, reading a magazine, and smoking a cigarette. ${ }^{48}$ Figure 1 shows the 1983 ad that evolved from these early tests. The headline, "Spoil Yourself With Satin", was accepted by the participants "without any hesitation and several spoke of 'deserving' time for themselves... 'she is totally relaxed, taking a break-dinner is done, kids are asleep—this is her time"'"23 (emphasis in original).

The 1982 Satin marketing strategy was "to convince the target that only Satin can pamper and gratify her special feminine needs and moods when it comes to smoking

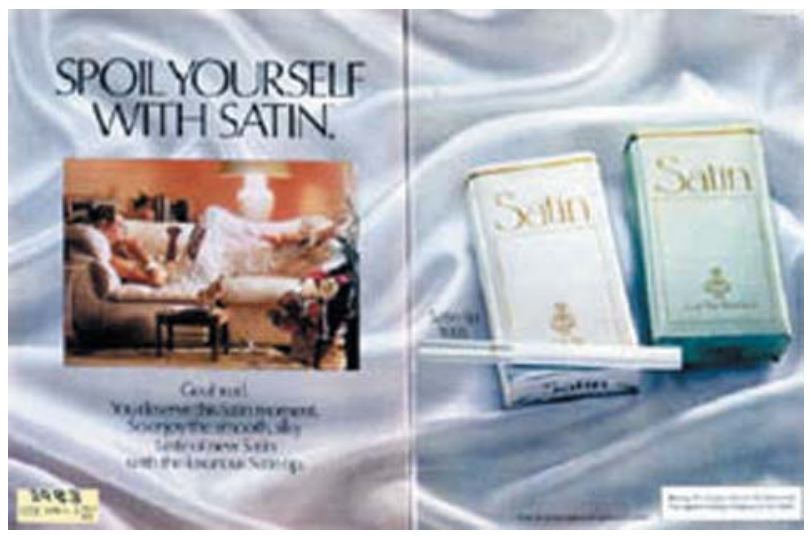

Figure 1 In this 1983 Satin "Couch" advertisement, the caption reads, "Go ahead. You deserve this Satin moment. So enjoy the smooth, silky taste of new Satin with the luxurious Satin tip". With the Satin brand and advertising campaigns, Lorillard attempted to capture a sensuous image of highly feminine-not feminist-women. This campaign was designed to communicate a self indulgent, relaxing, escapist fantasy for mature, busy women, whether employed or not, who felt pressured by many demands on their time.

\begin{tabular}{|c|c|c|c|c|}
\hline Need & Brand/company/campaign & Psychographic segment & Time period & Age group \\
\hline Private time $\mathrm{e}^{22} 23$ & $\begin{array}{l}\text { Satin (Lorillard): "Spoil } \\
\text { Yourself with Satin" }\end{array}$ & $\begin{array}{l}\text { "Social Strivers" and } \\
\text { "Satisfied Secures"" }\end{array}$ & $\begin{array}{l}\text { Early to mid } \\
1980 \text { s }\end{array}$ & $35-59$ \\
\hline $\begin{array}{l}\text { Social } \\
\text { acceptability }\end{array}$ & $\begin{array}{l}\text { Benson \& Hedges (Philip } \\
\text { Morris): "For People Who } \\
\text { Like to Smoke" }\end{array}$ & $\begin{array}{l}\text { "Imprisoned Smokers/ } \\
\text { Compensators" and "Closet } \\
\text { Smokers"25 }\end{array}$ & $\begin{array}{l}\text { Late } 1980 \mathrm{~s} \text { to } \\
\text { early } 1990 \mathrm{~s}\end{array}$ & $25-49$ \\
\hline Escape $^{29-33}$ & $\begin{array}{l}\text { Capri (Brown \& Williamson): } \\
\text { "She's Gone to Capri" }\end{array}$ & "Personal Experience" & $\begin{array}{l}\text { Mid 1990s to } \\
2000\end{array}$ & $35-59$ \\
\hline $\begin{array}{l}\text { Peer group } \\
\text { belonging }\end{array}$ & $\begin{array}{l}\text { Marlboro (Philip Morris): } \\
\text { "Marlboro Country" /"Come } \\
\text { to Where the Flavor Is" }\end{array}$ & "Mavericks" 2139 & $\begin{array}{l}\text { mid-1990s to } \\
2000 \text { s }\end{array}$ & $18-24$ \\
\hline $\begin{array}{l}\text { Female } \\
\text { camaraderie }^{4041}\end{array}$ & $\begin{array}{l}\text { Virginia Slims (Philip Morris): } \\
\text { "It's a Woman Thing" }\end{array}$ & "Uptown Girls"21 39 & $\begin{array}{l}\text { Mid 1990s to } \\
2000 \text { s }\end{array}$ & $20 \mathrm{~s}$ \\
\hline
\end{tabular}


enjoyment". ${ }^{49}$ Advertisements communicated the message on an emotional level: "The vignettes of relaxation, contemplation, and self-indulgence", according to executional plans, "must be real, but with an element of luxury that projects an aura of fantasy. They must evoke an emotional response from women". 49

Advertising for the brand, however, failed to create an ownable image for the target market. Women participating in focus groups perceived the ideal 1980s woman to be "a working woman with a family or possibly without, who enjoys working, enjoys her family and friends... but she is not overly independent to the point of being domineering, tough and isolated or in any way a woman's liber". ${ }^{50}$ Lorillard found it difficult to "depict the strategy of an active women, while utilizing visuals portraying relaxation" and made a decision to add "props or background hints suggesting a more active side of her life... an attaché case, working clothes, books". ${ }^{51}$ This technique may have interfered with the fantasy by including elements of the very things from which some in the target audience wished to escape.

Satin, though off to a strong start and still manufactured in 2004, was not a commercial success. Between test marketing and the national launch on 14 February $1983,{ }^{52}$ Satin claimed a $1.4 \%$ market share ${ }^{44}$ but failed to sustain it, dropping to a $0.24 \%$ share by the autumn of $1984 .^{53}$

\section{"For people who like to smoke": Benson \& Hedges and social acceptability}

As tobacco control advocates pressed for societal and legislative priority with respect to secondhand smoke, the social acceptability of smoking declined considerably ${ }^{54}$ Philip Morris (PM) asserted the importance of "counteract[ing] public campaigns aimed increasingly at convincing smokers and non-smokers that smoking is unacceptable in today's society".55 PM attempted advertising that would help smokers satisfy their increasingly salient need to be accepted by the society around them. "For People Who Like to Smoke" was the first of two campaigns designed to address social acceptability issues. After its failure to increase market share, PM again attempted to address social acceptability with the "Creative Solutions" campaign, also a failure, ${ }^{56}$ before abandoning the endeavour.

A 1985 marketing research presentation to Hamish Maxwell, PM chairman of the board and CEO, stated that smokers were primarily motivated by neither taste nor health issues: "these specific product attributes are used by the smoker only to place brands in a context related to their real need and concern - positive imagery for the smoker himself: The issue today is social acceptability" ${ }^{\prime 25}$ (emphasis in original).

The presentation noted that female smokers in particular "tend to see smoking as a negative activity... [and] react with new ways to compensate to increased pressure to stop/limit smoking"'25 (emphasis in original). Among those noted were "Imprisoned Smokers/Compensators", who are "embarrassed by social pressures... try to limit number [of cigarettes] smoked... [and] usually smoke 'acceptable' brands", and "'Closet' Smokers... older, predominantly female smokers... [who] often smoke only in private" ${ }^{25}$

Echoing PM's observations about the social acceptability concerns of female smokers, a 1987 report by RJ Reynolds on "new brands opportunities and supporting technologies" noted that "female smokers have a heightened want relative to male smokers" for improvement on the passive smoking issue, and that women were "more conscious of others objecting to smoking". ${ }^{57}$ Indeed, guilt seemed to be the cornerstone of the self concept of this segment with respect to being smokers. ${ }^{58}$
The author of the 1985 presentation to Maxwell recommended that cigarette campaigns contain messages that the smoker needed to hear about herself/himself as a smoker in a non-smoking world. The campaign should:

Tell me I am not personally offensive or unlovable because I smoke.

Tell me I am not a social outcast because I smoke.

Tell me smoking is not the most crucial choice in my life.

Tell me I am not different from everyone else just because I smoke $^{25}$ (emphasis in original).

The B\&H "For People Who Like to Smoke" campaign was designed to send smokers this message. The author of the report quoted above stated, "Benson \& Hedges taps into a deep reservoir of affection, because smokers, and particularly compensators, badly need to be told that smoking is a common part of everyday life". ${ }^{25}$ "Compensators" in this document refers to PM's "Imprisoned Smokers/ Compensators" segment. PM's 1988 B\&H creative strategy was to "utilize real smoking and nonsmoking people in spontaneous natural situations which reinforce the social acceptability of the Brand and the people who choose it... Smokers should never be perceived as lonely, isolated, 'stressed-out' or ostracized". ${ }^{27}$ All images comprising this campaign included non-smoking and smoking models in engaging, familiar, comfortable social interactions.

Focus group participants responded positively to these communications. Trinette Francis Qualitative Research reported results of 1988 focus groups of 18-44 year old smokers in New York and found the executions most successful in communicating social acceptability, normalcy, and inclusiveness in a comfortable setting were those which:

\section{- depict people interacting sympathetically or enjoying their privacy and time for themselves \\ - relate to people in situations which indicate a depth of emotional understanding \\ - where the smoker/nonsmoker dichotomy is relegated to the background. ${ }^{28}$}

The tagline "For people who like to smoke" implied to the respondents a sense of sharing: "we're allies as smokers", "it

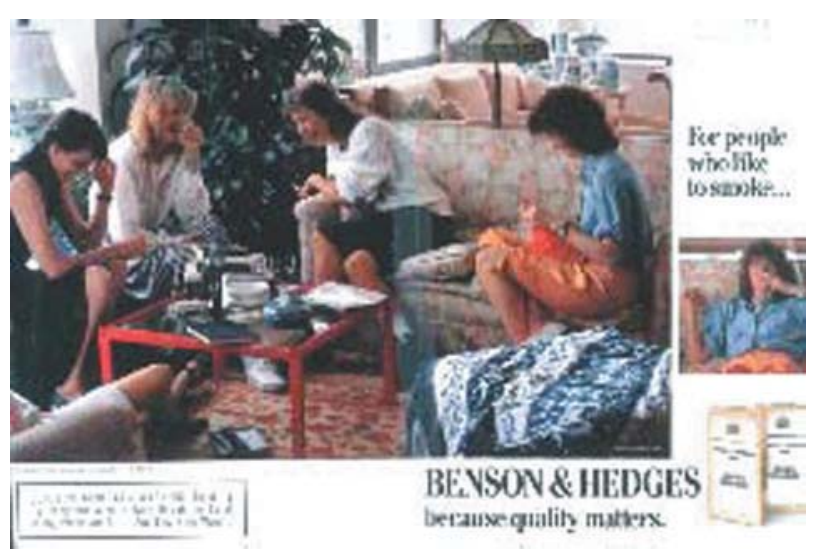

Figure 2 With the 1986 Benson \& Hedges "For People Who Like to Smoke" campaign "Living Room Girls" execution, PM attempted to combat the declining social acceptability of smoking through brand image. "For People Who Like to Smoke" depicted casual, jovial scenes of upper middle class people enjoying meaningful time with friends and family, where conflict between smokers and non-smokers was entirely absent. 
takes the stigma out of smoking" ${ }^{28}$ The ad most preferred by female participants, "Living Room Girls", appears in fig 2. Overall, "[s]mokers tended to feel good about the situations depicted in the 'For People Who Like to Smoke' campaign because of their personal experiences of not being able to smoke in many places. The ads, in a way, told them it's o.k., people do smoke and enjoy it". ${ }^{28}$

Despite its success in addressing a psychosocial need, the campaign did not succeed in making long term market share or profit gains for B\&H. In fact, throughout the campaign's lifecycle from 1986 to 1990, the brand experienced a steady decline in share. ${ }^{59-65}$ In the real world the social unacceptability of smoking remained; the fantasy of problem-free smoking depicted by the campaign was not enough to overcome reality.

\section{"She's Gone to Capri": offering a fantasy escape to older women}

As Graham noted, ${ }^{66}$ working class women were likely to perceive smoking as a psychological break from the many daily demands they faced. Similarly for middle and upper class women, Brown and Williamson (B\&W) launched a campaign in the 1990s, "She's Gone to Capri", that tapped the need of busy women to indulge in an escapist fantasy.

In 1980, B\&W attempted to develop a low tar cigarette for women who were 25-45 years old, white collar, middle or upper middle class, and relatively well educated. ${ }^{67}$ Capri was among several brands proposed, with a suggested brand personality designed to present:

...a moment of escape. The trip to a lovely foreign land where there are no phone calls, no kids, no demands... This is relaxation. It's a special experience; of that we can be sure. It's not Newport. It's not Miami Beach. It's exotic...romantic...exquisite... like nothing back home. ${ }^{68}$

The eventual users of Capri were about a decade older than the originally intended target, as psychographics overrode demographic targeting as the focus of the Capri advertising strategy. ${ }^{69}$

After eight years of evolving campaigns that too closely resembled 1980s Virginia Slims advertisements, ${ }^{70}$ a consulting firm B\&W hired in the 1990s, Tatham Euro RSCG, renewed Capri's positioning as an "Escape from the Ordinary" ${ }^{30}$ As the campaign proposal described:

[t]he Capri campaign invites women to make this escape through a combination of exotic, romantic visuals in a serene atmosphere; and confident women with a lyrical tone and manner... [The Capri woman's] emotional state can best be described as comfortable and quietly joyousabout herself, her surroundings, and her life. ${ }^{30}$

"The feelings associated with this escape", noted Stewart Young, group research director for Tatham Euro in a 1996 letter to B\&W's Sharon Smith, "are 'carefree,' 'peaceful,' 'relaxed' and 'quiet.' The ideal is often being alone, with one's own thoughts or feelings (alone but not lonely)". ${ }^{31}$

By 1997, the marketing research firm Perception Research Services, Inc, concluded that " $[\mathrm{t}]$ he current campaign for the Capri brand of cigarettes appears to easily transition/evolve toward the exclusion of models/people in the advertising. In many ways, it appears to strengthen the aspirational feel of the campaign, and make it more personally relevant/ compelling". ${ }^{71} \mathrm{~B} \& \mathrm{~W}$, concerned with possible future restrictions on tobacco advertising, ${ }^{72}$ pre-emptively developed a creative strategy where "the absence of a model rendered the setting more personal and more desirable", especially when
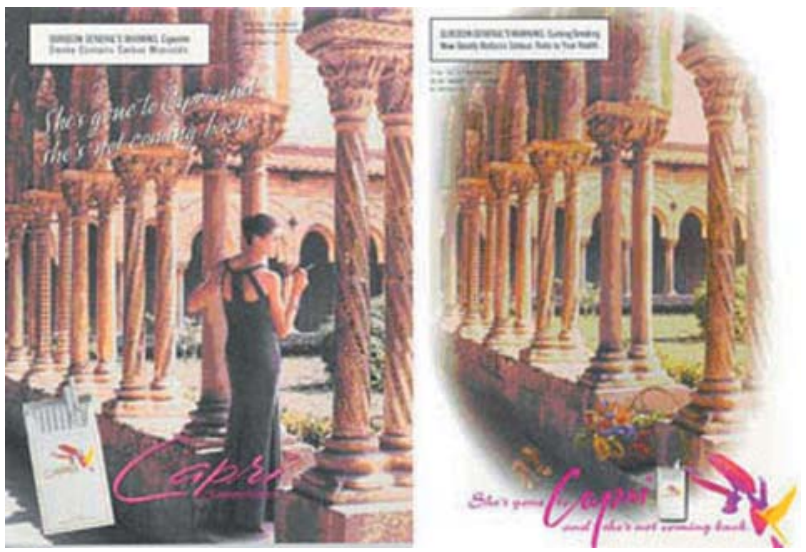

Figure 3 The left image from the 1997 Capri "She's Gone to Capri" campaign includes a model; the right image from 1999 excludes the model from the same scene. Like Satin, Capri targeted highly feminine women who felt a need for a luxurious escape from life's stresses. Brown \& Williamson found that excluding models from the ads and using impressionistic print techniques enhanced the dreamy, escapist feel of the image and created a more personal place to which the target audience could escape.

"models were removed from current ads and replaced with feminine props (hat, scarf, etc.)" ${ }^{72}$ Figure 3 demonstrates this change; the first image is an ad that ran in 1997 with the female model, and the second is the same scene in 1999 with the model removed. Joe Schurtz, vice president of Perception Research, summarised 1998 focus group testing, noting the absence of a model "allows each individual to place themselves in the setting and 'I can make it what I want to $^{\prime \prime \prime}$. $^{33}$

$\mathrm{B} \& \mathrm{~W}^{\prime}$ 's creative execution guidelines specified requirements for the late 1990s "She's Gone to Capri" images. First, the "location should not be in a crowded, loud or boisterous area but neither should it appear lonely or remote, but more simply put, a personal or private place".$^{32}$ Second, in the absence of models, "props should deliver the message that the CAPRI smoker has just momentarily stepped away. She is nearby". ${ }^{32}$ Additionally, the camera's distance from the scene "should be close in enough for the viewer to realize that the area is the personal space of a lady while at the same time enough background should be visible as to deliver the Mediterranean locale". ${ }^{32}$ Further, "the photograph is done with a technique that is pointillistic. The visual is not full bleed in order to appear like an old photograph" ${ }^{32}$ Schurtz explained how this technique might contribute to the escape: "The photographic style of softer/muted borders effectively reinforces images of elegance, mysterious and unique. This dream-like/escape feel can serve as the cornerstone for establishing the aspirational imagery of the brand." ${ }^{33}$

The "She's Gone to Capri" campaign became a transcendental fantasy of escape from the ordinary not in only the mundane sense of everyday hassles, but in a more holistic sense involving place, time, and emotion. The cigarette was subtly paired with this eminently pleasurable emotional state. $^{71}$ Capri was more successful than Satin; after a $0.41 \%$ share of market at its low in $1989,{ }^{73}$ Capri increased to $0.65 \%$ in $1996 .{ }^{74}$ As of 2004, B\&W lists Capri as one of its 12 "leading domestic brands", ${ }^{75}$ even though it has not surpassed Virginia Slims's $2.4 \%$ market share. ${ }^{76}$

\section{Young women's needs: Marlboro and Virginia Slims in} the 1990s

As manufacturer of two brands popular among women, PM tapped different female market segments with Marlboro and Virginia Slims. In a 1994 report, PM described four 
psychographic segments of the young adult (age 18-24 years) female market. The brands for young women discussed here target two of PM's segments: "Mavericks" for young female Marlboro users, and "Uptown Girls" for young Virginia Slims users. "Mavericks" were non-feminine women who gravitate toward exciting lifestyles and value independence; "Uptown Girls" were success oriented and status conscious partiers and shoppers. ${ }^{21} 39$

Though young female users of both of these brands highly value the peer groups to which they belong, ${ }^{41} 77$ the differences between these two groups may be seen in the strategies PM appears to have employed in designing the Marlboro advertisements of the 1990s and the concurrent Virginia Slims "It's a Woman Thing" campaign. For Marlboro, being an average person appears to be how young women gain a sense of belonging through their brand, whereas for Virginia Slims, stereotypic expression of gender differences appears to communicate youthful belonging.

\section{Marlboro}

Despite its overtly masculine image, Marlboro claims a larger percentage of young female smokers of any brand..$^{148}$ According to a Leo Burnett Agency presentation to PM in 1991, young female smokers described themselves as "dependable", "caring", "friendly", "fun", "easy to talk to", and "popular", and they most wanted to "belong to a reference group" and "fit in with peers". ${ }^{77}$ In a 1993 PM research presentation, young women saw Marlboro Lights as a brand for the casual, outgoing average person who gets along with anyone. ${ }^{35}$

New Marlboro images appeared in the 1990s that featured cowboys working, smiling, and laughing together. Figure 4 illustrates the change in ad imagery that may reflect PM's $^{\prime}$ attention to young women's values. The left image features the solitary Marlboro cowboy, stony faced, against a harsh, sun bleached backdrop of sand and scrub brush. The right features many cowboys laughing together in the soft, warm light of sunset. The "imagery of open spaces and individual freedom" that Marketing Perceptions, Inc, a market research agency hired by PM, found appealing to female Marlboro smokers $^{36}$ remained in the 1990s ads. PM may also have followed the recommendation of Bruce Eckman, Inc to make the Marlboro Man "more accessible and less removed (e.g., a smile, a touch, a tip of the hat)" ${ }^{38}$

\section{Virginia Slims}

Young female Virginia Slims users in the 1990s perceived their brand's image to be "more pretentious, more image conscious, more self-absorbed, and older" than that of
Marlboro Lights. ${ }^{77}$ This image contrasted with the values Leo Burnett identified as most important to young adult women smokers: fitting in and being popular but unpretentious. $^{77}$ When prompted to discuss the women's rights movement that had long been the theme of Virginia Slims advertising, young participants in 1991 focus groups explained that, "as beneficiaries of that Movement, maybe it wasn't all for the better... Men don't know how they're 'supposed' to treat women. And women don't know when and if it's okay to act feminine, or appreciate a "nicety"'. ${ }^{79}$ In additional focus groups, a participant stated, "I don't think it [women's movement] should go that far. It looks like we're going to an androgynous society". ${ }^{41}$ It was necessary for PM to remake the Virginia Slims brand image to be more relevant to the 1990s generation of young women. ${ }^{16}$

Stereotypical gender differences and a return to the traditional war of the sexes may act as a means of carving out the exclusive in-group to which women belong. Respondents in Marketing Perceptions' research said, "Women build really close friendships. Men don't seem to ever be as close... Guys go out to lunch to eat. Women go to chat". ${ }^{41}$ Similar statements are featured in Leo Burnett's

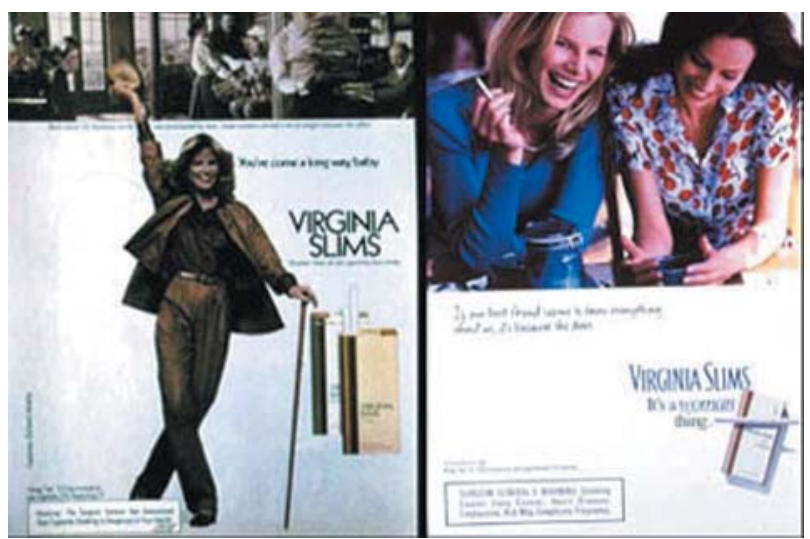

Figure 5 The left image is from the Virginia Slims "You've Come a Long Way, Baby" campaign in 1978; the right is from the "It's a Woman Thing" campaign in 1997. Virginia Slims' core user group was aging, and by the mid 1990s the feminist appeal of the long running "You've Come a Long Way, Baby" campaign was not well received by many younger women. PM recreated the Virginia Slims image by downplaying feminism and emphasising gender stereotyped female relationships. The caption of the right image reads, "If our best friend seems to know everything about us it's because she does. Virginia Slims. It's a woman thing"

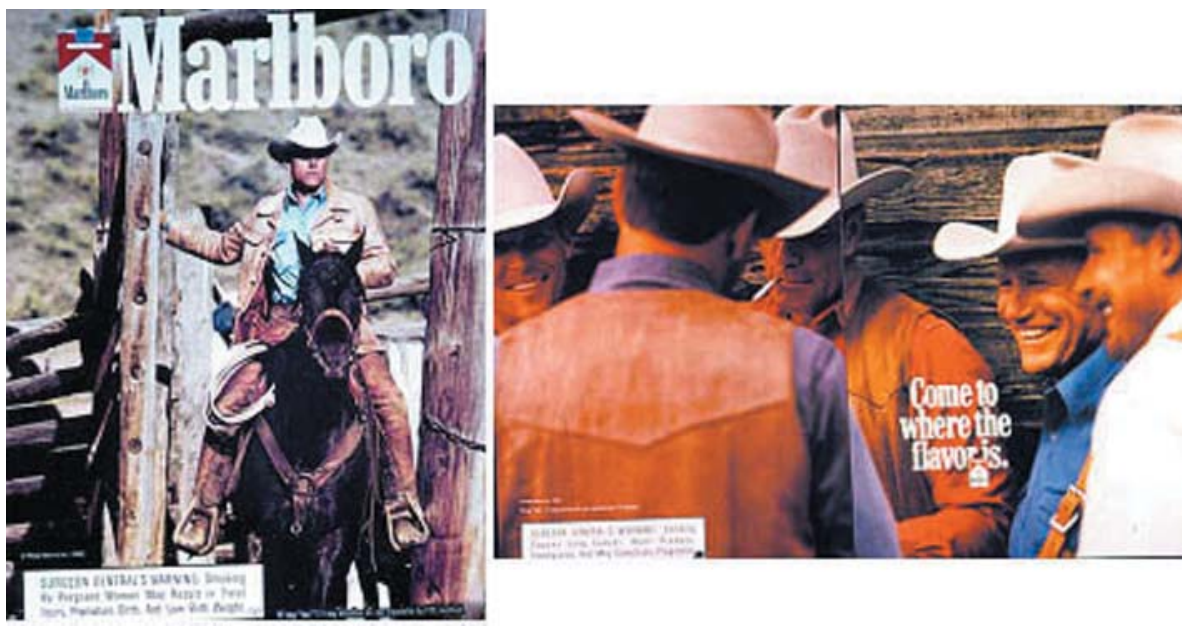

Figure 4 The left image of the stern and solitary cowboy is a Marlboro advertisement from 1960; the right image, updated to show friendly cowboys socialising, is from 1999. As the values of young people in the USA shiffed away from rugged individualism and toward a sense of community, PM attempted to update the Marlboro Man image to maintain relevance with the younger market. The Marlboro Man in the 1990s began to smile, socialise, enjoy leisure time, and show his softer more accessible side. 
subsequent "It's a Woman Thing" Virginia Slims campaign launched in 1996. The campaign attempted to make "statements about today's women that are universally understood". ${ }^{80}$ Virginia Slims brand's identity elaborated by Leo Burnett stated, "Virginia Slims... helps instill confidence in women by creating a 'sense of belonging' through relevant insights". "Figure 5 is an example of the shift from the feminist "You've Come a Long Way, Baby" campaign of the 1970s to the gender stereotypic "It's a Woman Thing" campaign of the 1990s.

\section{DISCUSSION}

We extend the current state of knowledge of women's cigarette advertising by revealing the industry's intentions of identifying and advertising to the psychosocial needs of different subgroups of women. Beyond simply cueing an ideal of thinness or independence, communicating satisfaction of psychosocial needs of different segments of women according to their age and motivations adds an important layer of complexity and subtlety to advertising. Cigarette advertisements designed to meet salient psychosocial needs often do not directly advertise cigarettes. Rather, such advertisements offer visuals that suggest needs satisfaction, and only by association do they introduce the brand of cigarettes as the means of satisfying needs.

A mechanism by which the association between psychosocial needs and a brand of cigarettes is accomplished has been suggested by Boyd et al. ${ }^{15}$ They presented a "means-end chain" by which the attributes of a product, the consequences of its use, and the consumer's values are linked in the consumer's mind by adept advertising. Specifically:

\section{A physical attribute of a cigarette is that it is made out of tobacco and contains nicotine... The psychosocial con- sequences of tobacco use may be related to self-image and psychological identification with thin bodies. A young woman who smokes cigarettes may think of herself as more likely to be slim and sophisticated or, alternatively, she may believe others will perceive her as more in control. Finally, instrumental and terminal values-the core ideals held by the woman-may include indepen- dence or liberation... [The] link between image and values is a consequence of the advertisement. ${ }^{15}$}

Similarly, our analysis shows that psychosocial needs identified by the industry as salient to women can be cued by advertising imagery. Communicating the cigarette's physical attributes was not a central goal in these marketing plans; the act of smoking and the cigarette itself are downplayed or left out of the images altogether. Market research to identify important psychosocial needs among the target audiences preceded the advertising campaigns.

Although the tobacco industry is not alone in marketing a product by eliciting a psychological state, attempts to sell cigarettes on the principle of satisfying women's psychosocial needs are inherently misleading. Attempting to satisfy a real psychosocial need with the counterfeit solution of smoking cigarettes both fails to address the need in a meaningful way and introduces a damaging addiction. Smoking may even exacerbate the underlying psychosocial need. Young women smoking to enhance social belonging alienate themselves from the non-smoking majority; older women smoking as a means of escaping life's demands burden themselves with the additional demand of addiction.

The strategies we outlined are most likely not limited to female markets. Evidence of the industry's efforts to target other special populations suggests that these strategies are commonly practiced. Young African American adult smokers, ${ }^{81}$ the lesbian, gay, bisexual, and transgender community, ${ }^{82}$ Asian Americans, ${ }^{83}$ youth, ${ }^{84}$ and young adults of both sexes ${ }^{85}$ have been targeted with psychological, social, or emotional appeals in tobacco advertising. Our results demonstrate the subtlety of targeting female smokers' needs with imagery that does not overtly focus on, and in some cases excludes altogether, the act of smoking.

\section{Implications for tobacco control policy}

Our results have implications for two tobacco control policies: complete advertising bans, and targeted counter-advertising.

\section{Advertising bans}

The advertising strategies discussed here present a particular challenge to tobacco control. Cigarette advertising can communicate a subtle message of psychosocial needs satisfaction, often purposefully disconnected from the characteristics of the cigarette or the act of smoking. Further, our analysis of the Capri campaign suggests that advertising may be able to communicate needs satisfaction more intimately by presenting images that exclude models. This form of advertising to women circumvents voluntary advertising restrictions that explicitly prohibit use of female models or people holding cigarettes, such as those used in the past in Japan. ${ }^{86}{ }^{87}$ Total bans on all forms of cigarette advertising and promotion have enjoyed some success. For example, smoking rates in Australia, where all tobacco advertising is strictly banned, dropped from $22 \%$ in 1998 to $19.5 \%$ three years later, and the proportion of never smokers increased in that time period. ${ }^{8}$ Around the world, the tobacco industry works to weaken or delay comprehensive advertising bans ${ }^{89-91}$ and to develop new marketing strategies that circumvent them..$^{92-94}$ The advertising principles outlined in this paper are not adequately addressed by current advertising restrictions in the USA. Given that advertising images are capable of delivering the desired psychological communication without the inclusion of cigarettes, smoking imagery, or even models, these campaigns rob advertising bans of potency.

Our results explain how tobacco advertising targeting women is constructed to circumvent advertising bans and may provide a framework for analysing advertising targeting other populations. Evidence suggests that comprehensive advertising bans are more effective than partial bans. ${ }^{95} \mathrm{~A}$ comprehensive ban on all forms of advertising and promotions would better address the advertising principles demonstrated in this study.

\section{Counter-advertising}

Counter-advertising that denormalises smoking and the tobacco industry, such as the Truth campaign and California's tobacco control media campaigns, have been effective, ${ }^{96-98}$ especially when well funded, long running, and accompanied by other tobacco control measures. ${ }^{99}$ Our results suggest that counter-advertising can be designed to undermine the message that smoking a brand of cigarettes provides needs satisfaction. For example, a message of escape from life's hassles may be countered with a message that addiction further complicates an already hassle ridden life. "Adbusting" attacks ${ }^{100}$ directly refute advertising messages and often call the viewer to question implicit brand associations.

Counter-advertising can also provide an alternative means to fulfil a psychosocial need. Counter-advertising can be assessed by its ability to provide alternatives to pro-smoking associations formed by tobacco advertising that resonate with the psychosocial needs of each target audience. The teen focused "Truth" campaign, comprised of advertisements featuring youths confronting the tobacco industry, is a campaign that effectively addresses a psychosocial need: in 


\section{What this paper adds}

Previous studies have documented that the tobacco industry targets women with advertising, but less is known about what specific psychosocial communications in advertisements effectively promote smoking among women.

Our research provides evidence from the advertisers themselves that targeting the psychosocial needs of women of different ages is the overt intent of cigarette advertisers. Using previously secret tobacco industry documents, we demonstrate how the tobacco industry identifies women's psychosocial needs and constructs advertising images planned explicitly to suggest satisfaction of those needs. This evidence helps to explain why partial bans on cigarette advertising are ineffective; it also suggests that targeted counter-advertising should address women's psychosocial needs.

this case, youths' need to assert their independence and individuality. ${ }^{97}$

Counter-advertising may also call attention to an offensive industry strategy. Not all industry efforts to target the psychosocial needs of women were successful-for example, Lorillard failed to consolidate a clear and universally appealing image of the Satin Woman for their older female target audience. It is useful to ask if, indeed, older women do frequently wish to indulge in escapist fantasies, or if they may be offended by the industry's suggestion that they are not willing or able to cope with the pressures of their daily lives. The gender stereotyping on which such cigarette advertisements rely may be insulting to many women. These sentiments can be used to frame counter-advertising or advocacy campaigns, as when public outcry over RJ Reynolds' "Dakota" campaign targeting low income women was followed by a quick withdrawal of all Dakota promotional efforts. ${ }^{5}$

\section{Conclusion}

Cigarette advertising messages have moved away from more easily refuted ideas about the supposed benefits of smoking and toward more subtle and emotionally engaging messages about the satisfaction of needs that are unrelated to smoking. This form of advertising is both difficult for audiences to analyse in a rational manner and impossible to control with partial advertising bans. Ad bans should be comprehensive and should include all forms of advertising and promotion. Counter-advertising campaigns should expose the process of associating cigarettes with desirable psychological states and return the negative affect surrounding smoking to its proper place: on the industry's predatory marketing practices and the profits it gains from encouraging the consumption of a deadly product.

\section{ACKNOWLEDGEMENTS}

We would like to thank the faculty and fellows of the Institute for Health Policy Studies at the University of California, San Francisco for their extensive comments on previous drafts of this work. We are grateful to Dr Virginia Ernster for allowing us access to her collection of tobacco advertisements targeting women.

This work was supported by the American Legacy Foundation and National Cancer Institute grant number CA-87472

\section{Authors' affiliations}

S J Anderson, S A Glantz, P M Ling, Center for Tobacco Control Research and Education, University of California, San Francisco, San Francisco, California, USA

\section{REFERENCES}

1 Patel JD, Bach PB, Kris MG. Lung cancer in US women: a contemporary epidemic. JAMA 2004;291:1763-8.

2 Shafey $O$, Fernandez $E$, Thun $M$, et al. Cigarette advertising and female smoking prevalence in Spain, 1982-1997: case studies in International Tobacco Surveillance. Cancer 2004; 100:1744-9.

3 Christen AG, Christen JA. The female smoker: from addiction to recovery. Am J Med Sci 2003;326:231-4.

4 Mackay J, Amos A. Women and tobacco. Respirology 2003;8:123-30.

5 US Department of Health and Human Services. Women and smoking: a report of the Surgeon General - 2001. Washington DC: US Department of Health and Human Services, Centers for Disease Control and Prevention, National Center for Chronic Disease Prevention and Health Promotion, Office on Smoking and Health, 2001.

6 Scott WD. Influencing men in business: the psychology of argument and suggestion, 3rd ed. New York: Ronald Press Company, 1911

7 Koponen A. Personality characteristics of purchasers. J Ad Research 1960;1:6-12.

8 Plummer JT. Life style patterns and commercial bank credit card use. J Marketing 1971;35:35-41.

9 Rokeach M. The nature of human values. New York: Free Press, 1973.

10 Demby E. Psychographics: Who, what, why, when, where and how. In: King C, Tigert D, eds. Attitude research reaches new heights. Chicago: American Marketing Association, 1971:196-199.

11 O'Keefe AM, Pollay RW. Deadly targeting of women in promoting cigarettes. $J$ Am Med Women Assoc 1996;51:67-9.

12 Cawley J, Markowitz S, Tauras J. Lighting up and slimming down: the effects of body weight and cigarette prices on adolescent smoking initiation. $J$ Health Econ 2004;23:293-311.

13 Honjo K, Siegel M. Perceived importance of being thin and smoking initiation among young girls. Tobacco Control 2003; 12:289-95.

14 Campaign for Tobacco-Free Kids (Author Implied). Campaign for Tobacco Free Kids Background Info on Women, Girls and Tobacco. US NEWSWIRE. Philip Morris; 2001. Legacy Tobacco Documents Library. Bates No. 2081616363D/6367. http://legacy.library.ucsf.edu/tid/rvv81c00 (Accessed 9 Jun 2004).

15 Boyd TC, Boyd CJ, Greenlee TB. A means to an end: slim hopes and cigarette advertising. Health Promot Pract 2003;4:266-77.

16 Toll BA, Ling PM. The Virginia Slims identity crisis: an inside look at tobacco industry marketing to women. Tobacco Control 2005 (in press).

17 Barbeau EM, Leavy-Sperounis, A, Balbach, eds. Smoking, social class, and gender: What can public health learn from the tobacco industry about disparities in smoking? Tobacco Control 2004;13:115-20.

18 Amos A. How women are targeted by the tobacco industry. World Health Forum 1990;11:416-22.

19 Amos A, Haglund M. From social taboo to "torch of freedom": the marketing of cigarettes to women. Tobacco Control 2000;9:3-8.

20 Cox AR. Established Brands Positioning and Evaluation Process Summary. Lorillard; 1984. Legacy Tobacco Documents Library. Bates No. 93285082/ 5109. http://legacy.library.ucsf.edu/tid/hfl60e00 (Accessed 24 Mar 2004).

21 Ling PM, Glantz SA. Using tobacco-industry marketing research to design more effective tobacco-control campaigns. JAMA 2002;287:2983-9.

22 Hoefer GM. F 1. MCA Advertising, editor. Lorillard; 1981. Legacy Tobacco Documents Library. Bates No. 89923427/3430. http:// legacy.library.ucsf.edu/tid/oim80e00 (Accessed 24 Mar 2004).

23 Russell Marketing Research. Satin Ad Study Focus Group Sessions No. 110 61. Russell Marketing Research. Lorillard; 1981. Legacy Tobacco Documents Library. Bates No. 89923433/3533. http://legacy.library.ucsf.edu/tid/ ycd30e00 (Accessed 24 Mar 2004).

24 Goldstein LR. Comparison of Satin Image Study and Segmentation Study. LOR L. Lorillard; 1985. Legacy Tobacco Documents Library. Bates No. 89839961/ 9962. http://legacy.library.ucsf.edu/tid/rot13c00 (Accessed 19 Sep 2004).

25 Philip Morris. Presentation to Hamish Maxwell 851119. Philip Morris; 1985. Legacy Tobacco Documents Library. Bates No. 2023177676/7709. http:// legacy.library.ucsf.edu/tid/vdy74e00 (Accessed 2 Jul 2004).

26 Bonhomme J, Durante J. Marketing Research Department Report Attitude Towards Smoking Brand Segmentation Study. PM PM. Philip Morris; 1989. Legacy Tobacco Documents Library. Bates No. 2040667437/7448. http:// legacy.library.ucsf.edu/tid/gpf52e00 (Accessed 8 Apr 2004).

27 Philip Morris. Benson \& Hedges 880000 Marketing Plan Executive Summary. Philip Morris; 1988. Legacy Tobacco Documents Library. 2026308637/ 8724. http://legacy.library.ucsf.edu/tid/yxy83e00 (Accessed 24 Mar 2004).

28 Trinette Francis. Qualitative Research : Advertising for Benson \& Hedges. TRINETTE FRANCIS. Philip Morris; 1988. Legacy Tobacco Documents Library. Bates No. 2043293205/3253. http://legacy.library.ucsf.edu/tid/ mmw95e00 (Accessed 24 Mar 2004).

29 Brown and Willamson. No Title. Brown and Williamson; 1980. Legacy Tobacco Documents Library. Bates No. 544000497/0504. http:// legacy.library.ucsf.edu/tid/mgh $10 f 00$ (Accessed 24 Mar 2004).

30 Tatham Euro RSCG. Brand Equity Exploration Capri Superslims. Escape From the Ordinary. Brown and Williamson; 1995. Legacy Tobacco Documents Library. Bates No. 433010333/0403. http://legacy.library.ucsf.edu/tid/ yhd90fo0 (Accessed 24 Mar 2004).

31 Young S. The Capri Consumer S "Ideal Escape". RSCG TE. Brown and Williamson; 1996. Legacy Tobacco Documents Library. Bates No. 461232488/2489. http://legacy.library.ucsf.edu/tid/tli81d00 (Accessed 9 Apr 2004).

32 Brown and Williamson. Capri; Creative Execution Guidelines for Print Advertising. Brown and Williamson; Date Unknown. Legacy Tobacco 
Documents Library. Bates No. 439030010/0013. http:// legacy.library.ucsf.edu/tid/hcul2d00 (Accessed 9 Apr 2004).

33 Schurtz J. Summation of Capri Post Shoot Qualitative. Services PR. Brown and Williamson; 1998. Legacy Tobacco Documents Library. Bates No. 432201822/1830. http://legacy.library.ucsf.edu/tid/inel 1c00 (Accessed 9 Apr 2004)

34 McCann-Erickson Inc. Social Trends among Female Smokers Application to Project Delta. Brown and Williamson; 1981. Legacy Tobacco Documents Library. Bates No. 677046078/6107. http://legacy.library.ucsf.edu/tid/ wzi $13 f 00$ (Accessed 24 Mar 2004)

35 Philip Morris. Young Adult Women Attitudes Lifestyles Brand Images. Philip Morris; 1993. Legacy Tobacco Documents Library. Bates No. 2045812061/ 2116. http://legacy.library.ucsf.edu/tid/cag06e00 (Accessed 7 Apr 2004).

36 Marketing Perceptions Inc. Marlboro Promotion Programs a Qualitative Research Summary. Marketing Perceptions. Philip Morris; 1992. Legacy Tobacco Documents Library. Bates No. 2047523245/3254. http:// legacy.library.ucsf.edu/tid/grp72e00 (Accessed 25 Mar 2004).

37 Philip Morris. European Young Adults a Study of Values, Lifestyles and Brand Images. PM-EEC P-E. Philip Morris; 1992. Legacy Tobacco Documents Library. Bates No. 2500150875/1042. http://legacy.library.ucsf.edu/tid/ qub42e00 (Accessed 7 Apr 2004).

38 Eckman B, Goldberg S. The Viability of the Marlboro Man among the 1824 Segment. Bruce Eckman. Philip Morris; 1992. Legacy Tobacco Documents Library. Bates No. 2040837853/7879. http://legacy.library.ucsf.edu/tid/ oyi92e00 (Accessed 8 Apr 2004).

39 Ansberry C, O'Boyle TF, Roberts JT. Today's Adult Young Male Smoker. Wall Street Journal. Philip Morris; 1994. Legacy Tobacco Documents Library. Bates No. 2060127742/7919. http://legacy.library.ucsf.edu/tid/leg76e00 (Accessed 24 Mar 2004).

40 Leo Burnett Agency. Virginia Slims "II's a Woman Thing" Pool 5 Pre Production Meeting. LEO LBA. Philip Morris; 1998. Legacy Tobacco Documents Library. Bates No. 2081177327/7375. http:// legacy.library.ucsf.edu/tid/uec30c00 (Accessed 24 Mar 2004).

41 Marketing Perceptions Inc. An Exploration of Women's Issues a Qualitative Research Report. Marketing Perceptions. Philip Morris; 1994. Legacy Tobacco Documents Library. Bates No. 2048964928/5007. hitp:// legacy.library.ucsf.edu/tid/ubu81 foo (Accessed 24 Mar 2004).

42 Lorillard. 6 Week Test Market Aau. Lorillard; 1982. Legacy Tobacco Documents Library. Bates No. 85129623. http://legacy.library.ucsf.edu/tid/ bsb31e00 (Accessed 24 Mar 2004).

43 Lorillard (Author Implied). A Qualitative Exploration of How Women Are Portrayed in Advertising. MRD. Lorillard; 1980. Legacy Tobacco Documents Library. Bates No. 87060629/0655. http://legacy.library.ucsf.edu/tid/ fsy30e00 (Accessed 17 Jun 2004).

44 Anon. Satin, A Proven Success, Test Market Results. American Tobacco; 1983. Legacy Tobacco Documents Library. Bates No. 950436359/6374. http://legacy.library.ucsf.edu/tid/iej15fo0 (Accessed 24 Mar 2004).

45 Lorillard. Communication Test. Lorillard; 1982. Legacy Tobacco Documents Library. Bates No. 85129624/9625. hitp://legacy.library.ucsf.edu/tid/ csb31e00 (Accessed 21 Jun 2004).

46 Russell Marketing Research. Cigarette Concept Study Number 01148 Focus Group Sessions. Russell Marketing Research. Lorillard; 1981. Legacy Tobacco Documents Library. Bates No. 89899800/9860. http:// legacy.library.ucsf.edu/tid/xmr70e00 (Accessed 24 Mar 2004).

47 Lorillard. Qualitative Research. Lorillard; 1981. Legacy Tobacco Documents Library. Bates No. 85129629/9630. http://legacy.library.ucsf.edu/tid/ esb3le00 (Accessed 21 Jun 2004).

48 Contemporary Marketing Research. Satin Cigarette Concept Final Report. Contemporary Marketing Research. Lorillard; 1982. Legacy Tobacco Documents Library. Bates No. 89924477/4513. http:// legacy.library.ucsf.edu/tid/gkm80e00 (Accessed 27 May 2004).

49 MCA Advertising. Satin Creative Strategy (Print). MCA Advertising. Lorillard 1982. Legacy Tobacco Documents Library. Bates No. 93112870 . http:// legacy.library.ucsf.edu/tid/icm60e00 (Accessed 24 Mar 2004).

50 Tracy Research. Qualitative Evaluation of Vignettes for Satin Cigarettes. Tracy Research. Lorillard; 1984. Legacy Tobacco Documents Library. Bates No. 89844245/4314. http://legacy.library.ucsf.edu/tid/aps70e00 (Accessed 24 Mar 2004).

51 Lorillard. Qualitative Research of Satin Imagery. Lorillard; 1983. Legacy Tobacco Documents Library. Bates No. 85129609/9610. hittp:// legacy.library.ucsf.edu/tid/prb31e00 (Accessed 8 Apr 2004)

52 Lorillard. 12 Week National Aau. Lorillard; 1983. Legacy Tobacco Documents Library. Bates No. 85129615. http://legacy.library.ucsf.edu/tid/ urb3le00 (Accessed 21 Jun 2004).

53 American Tobacco. New Brands Share Of Market, Three Months Ending November 1984. American Tobacco; 1984. Legacy Tobacco Documents Library. Bates No. 970277860. http://legacy.library.ucsf.edu/tid/ctm35f00 (Accessed 8 Apr 2004).

54 Glantz SA, Slade J, Bero LA, et al. The cigarette papers. Berkeley: University of California Press, 1996.

55 Philip Morris International. Philip Morris International 800000 Corporate Affairs. PM PM. Philip Morris; 1980. Legacy Tobacco Documents Library. Bates No. 2048129267/9296. http://legacy.library.ucsf.edu/tid/rbr42d00 (Accessed 9 Jun 2004).

56 Smith EA, Malone RE. "Creative Solutions": selling cigarettes in a smoke-free world. Tobacco Control 2004;13:57-63.

57 RJ Reynolds. New Brands Opportunities and Supporting Technologies. RJ Reynolds; 1987. Legacy Tobacco Documents Library. Bates No. 506786513/ 6540. http://legacy.library.ucsf.edu/tid/hhh44d00 (Accessed 16 Apr 2004).
58 RJ Reynolds. Improved Aroma Social Acceptability. RJ Reynolds; 1985 Legacy Tobacco Documents Library. Bates No. 506084952/4956. http:// legacy.library.ucsf.edu/tid/znz18c00 (Accessed 16 Apr 2004).

59 Anise R. Cigarette Brand Share 890600. PM PM. Philip Morris; 1989. Legacy Tobacco Documents Library. Bates No. 2040306633/6666. http:// legacy.library.ucsf.edu/tid/snx94e00 (Accessed 8 Apr 2004).

60 Desimone L. Preliminary Volume and Share Estimates 900700 . PMUSA PMU. Philip Morris; 1990. Legacy Tobacco Documents Library. Bates No. 2073009127/9148. hitp://legacy.library.ucsf.edu/tid/dis57c00 (Accessed 8 Apr 2004)

61 Anise R. Cigarette Brand Share 910200. PM PM. Philip Morris; 1991. Legacy Tobacco Documents Library. Bates No. 2048064529/4567. http:// legacy.library.ucsf.edu/tid/mgs82e00 (Accessed 8 Apr 2004).

62 Anise R. Cigarette Brand Share 910800. PM PM. Philip Morris; 1991. Legacy Tobacco Documents Library. Bates No. 2040330159/0200. hitp:// legacy.library.ucsf.edu/tid/ofz94e00 (Accessed 8 Apr 2004).

63 Anise R. Cigarette Brand Share 911 200. PM PM. Philip Morris; 1992. Legacy Tobacco Documents Library. Bates No. 2060096040/6081. http:// legacy.library.ucsf.edu/tid/kke72e00 (Accessed 8 Apr 2004).

64 Anise R. Cigarette Brand Share 930100. PMUSA PMU. Philip Morris; 1993. Legacy Tobacco Documents Library. Bates No. 2073360042/0083. http:// legacy.library.ucsf.edu/tid/wav57c00 (Accessed 8 Apr 2004).

65 Gawronski E. Cigarette Shipment Brand Share Report 951 100. PM PM. Philip Morris; 1995. Legacy Tobacco Documents Library. Bates No. 2048024553/ 4591. http://legacy.library.ucsf.edu/tid/ocs65e00 (Accessed 8 Apr 2004).

66 Graham H. Women's smoking and family health. Soc Sci Med 1987:25:47-56.

67 Alar J, Heger C, McCafferty B, et al. Bwt USA Major Marketing Decision Recommendation Project Delta. Brown and Williamson; 1980. Legacy Tobacco Documents Library. Bates No. 544000538/0548. http:// legacy.library.ucsf.edu/tid/mpc43fo0 (Accessed 24 Mar 2004).

68 Brown and Willamson. Project Delta an Ultra Low Tar Cigarette for Women. Brown and Williamson; 1980. Legacy Tobacco Documents Library. Bates No. 544000505/0511. http://legacy.library.ucsf.edu/tid/ngh $10 f 00$ (Accessed 24 Mar 2004)

69 Brown and Williamson. Capri Trademark Positioning. Brown and Williamson; Date Unknown. Legacy Tobacco Documents Library. Bates No. 502030402/041 1. http://legacy.library.ucsf.edu/tid/gvt02d00 (Accessed 9 Apr 2004)

70 Analytic Insight Inc. Capri: New Creative Evaluation. Brown and Williamson; 1988. Legacy Tobacco Documents Library. Bates No. 681803027/3087. http://legacy.library.ucsf.edu/tid/pug60fo0 (Accessed 24 Mar 2004).

71 Perception Research Services. A Qualitative Exploration of the Capri Print Advertising Campaign; \#143 $24 \mathrm{Fg} 697$. Brown and Williamson; 1997. Legacy Tobacco Documents Library. Bates No. 502030531/0551. http:// legacy.library.ucsf.edu/tid/hut02d00 (Accessed 9 Apr 2004).

72 Brown and Williamson. Capri 1998 Creative Plans. Brown and Williamson; 1998. Legacy Tobacco Documents Library. Bates No. 315022066/2076. http://legacy.library.ucsf.edu/tid/bzv02d00 (Accessed 19 Sep 2004).

73 Denkhoff E. MSA Share of Market Reports for Capri Test/Expansion Markets. Brown and Williamson; 1989. Legacy Tobacco Documents Library. Bates No. 465603663/3670. http://legacy.library.ucsf.edu/tid/ihu20fo0 (Accessed 9 Apr 2004).

74 Brown and Williamson. Share Data; Profit Contribution; Capri Styles Distribution by Channel; Strong Channels for Capri. Brown and Williamson; 1998. Legacy Tobacco Documents Library. Bates No. 502030594/0600. http://legacy.library.ucsf.edu/tid/kut02d00 (Accessed 22 Jun 2004).

75 Brown and Williamson. About our Brands. 2004. http:// www.brownandwilliamson.com/Index_sub2.cfm?ID = 11 (Accessed 16 Apr 2004).

76 Altria Group Inc. Business Review Philip Morris USA Inc. Domestic Tobacco. 2004. http://www.altria.com/annualreport2003/ar2003_05_0100.asp (Accessed 16 Apr 2004).

77 Leo Burnett Agency. The Young Adult Woman Smoker. LEO LBA. Philip Morris; 1991. Legacy Tobacco Documents Library. Bates No. 2073365787/ 5923. http://legacy.library.ucsf.edu/tid/syv57c00 (Accessed 24 Mar 2004).

78 Philip Morris. Leading Brand Share among Female Yas Versus Yag. Philip Morris; 1999. Legacy Tobacco Documents Library. Bates No. 2078770952 http://legacy.library.ucsf.edu/tid/iik91c00 (Accessed 17 Jun 2004).

79 Marketing Perceptions Inc. Exploring Attitudes, Lifestyles and Generational Statements of Young Adult Women a Qualitative Research Study. Marketing Perceptions. Philip Morris; 1991. Legacy Tobacco Documents Library. Bates No. 2042942418/2448. http://legacy.library.ucsf.edu/tid/dfn95e00 (Accessed 24 Mar 2004).

80 Philip Morris. Virginia Slims Music Communications Plan. Philip Morris; 1994. legacy Tobacco Documents Library. Bates No. 2040223958/3960. http://legacy.library.ucsf.edu/tid/oeo76e00 (Accessed 24 Mar 2004).

81 Balbach ED, Gasior RJ, Barbeau EM. R.J. Reynolds' targeting of African Americans: 1988-2000, Am J Public Health 2003;93:822-7.

82 Smith EA, Malone RE. The outing of Philip Morris: advertising tobacco to gay men. Am J Public Health 2003;93:988-93.

83 Muggli ME, Pollay RW, Lew R, et al. Targeting of Asian Americans and Pacific Islanders by the tobacco industry: results from the Minnesota Tobacco Document Depository. Tobacco Control 2002;11:201-9.

84 Pollay RW. Targeting youth and concerned smokers: evidence from Canadian tobacco industry documents. Tobacco Control 2000;9:136-47.

85 Ling PM, Glantz SA. Why and how the tobacco industry sells cigarettes to young adults: evidence from industry documents. Am J Public Health 2002;92:908-16.

86 Mizuno S, Telling W, Ikeda T. Outline of Main Business. Voluntary Rules On Advertising \& Sales Promotion. Japan TIO. Brown and Williamson; 1990. 
Legacy Tobacco Documents Library. Bates No. 510300501/0511. http:// legacy.library.ucsf.edu/tid/xim51 f00 (Accessed 22 Jun 2004).

87 Philip Morris International. Japan (Voluntary Restrictions). PMI PMI. Philip Morris; 1990. Legacy Tobacco Documents Library. Bates No. $2501144932 /$ 4933. http://legacy.library.ucsf.edu/tid/cdu32e00 (Accessed 22 Jun 2004).

88 Australian Institute of Health and Welfare. 2001 National Drug Strategy Household Survey: First Results. AlHW cat. no. PHE 35. Canberra: AlHW (Drug Statistics Series No, 9). Canberra: Australian Institute of Health and Welfare; 2002. Report No.: AlHW cat. no. PHE 35. Canberra: AlHW (Drug Statistics Series No. 9).

89 Neuman M, Bitton A, Glantz S. Tobacco industry strategies for influencing European Community tobacco advertising legislation. Lancet 2002;359:1323-30.

90 Cornuz J, Burnand B, Kawachi I, et al. Why did Swiss citizens refuse to ban tobacco advertising? Tobacco Control 1996;5:149-53.

91 Simpson D. Germany: bogus polls and the Euro-pain syndrome. Tobacco Control 2002;11:90.

92 Carter SM. Going below the line: creating transportable brands for Australia's dark market. Tobacco Control 2003;12(suppl III):iii87-94.

93 Celebucki CC, Diskin K. A longitudinal study of externally visible cigarette advertising on retail storefronts in Massachusetts before and after the Master Settlement Agreement. Tobacco Control 2002; 11 (supple II):ii47-53.

94 Carter SM. New frontier, new power: the retail environment in Australia's dark market. Tobacco Control 2003;12(suppl III): iii95-101.

95 Wakefield M, Chaloupka F. Effectiveness of comprehensive tobacco control programmes in reducing teenage smoking in the USA. Tobacco Control 2000;9:177-86.

96 Goldman LK, Glantz SA. Evaluation of antismoking advertising campaigns. JAMA 1998;279:772-7.

97 Farrelly MC, Healton CG, Davis KC, et al. Getting to the truth: evaluating national tobacco countermarketing campaigns. Am J Public Health 2002;92:901-7.

98 Hicks JJ. The strategy behind Florida's "truth" campaign. Tobacco Control 2001;10:3-5.

99 Levy DT, Chaloupka F, Gitchell J. The effects of tobacco control policies on smoking rates: a tobacco control scorecard. J Public Health Manag Pract 2004; 10:338-53.

100 Chapman S. Civil disobedience and tobacco control: the case of BUGA UP. Billboard Utilising Graffitists Against Unhealthy Promotions. Tobacco Control 1996;5:179-85.

\section{The Lighter Side}

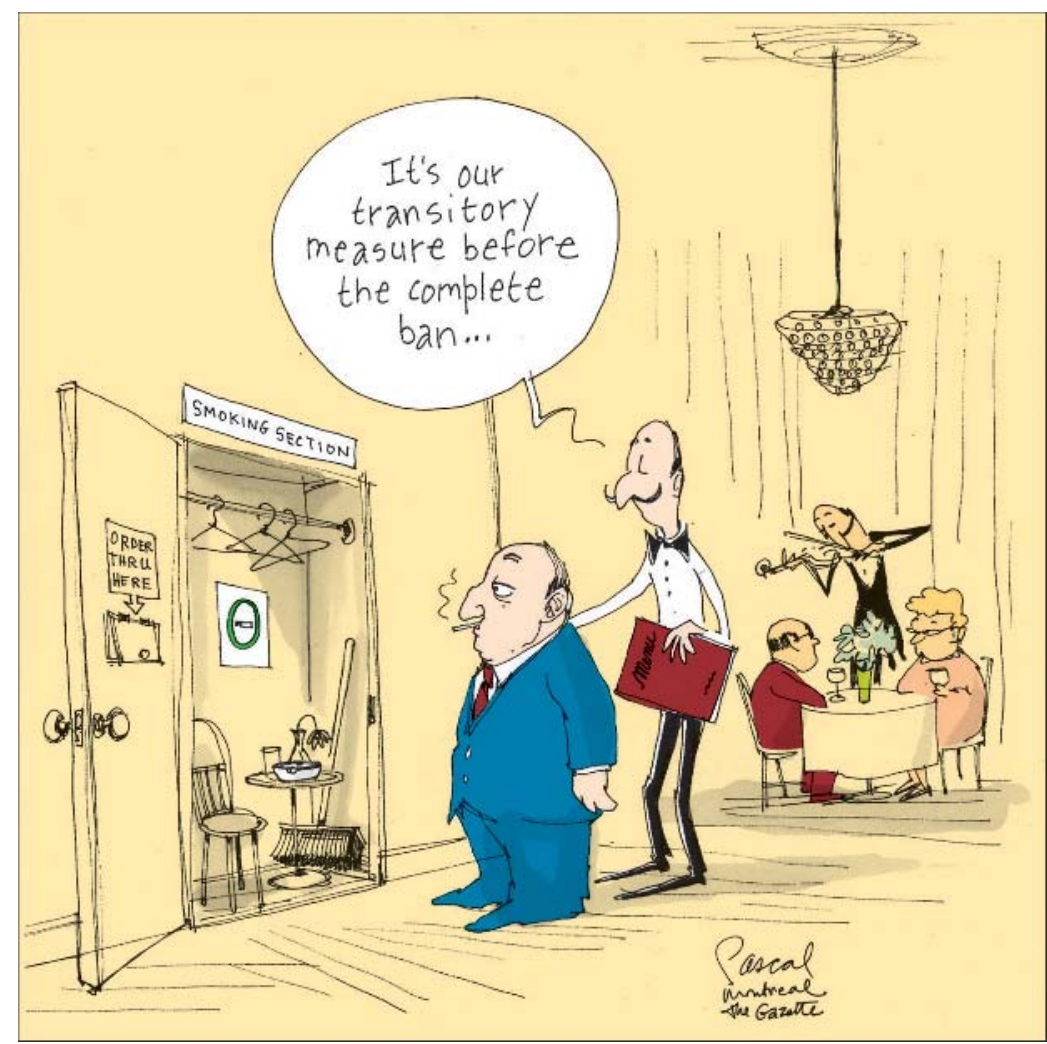

The Health Minister of Quebec announces plans to improve the Canadian province's Tobacco Act, eliminating all smoking from restaurants, bars, and other places inadequately covered by the existing law. () Pascal 2005. 